\title{
Poglądy bioetyczne i ekofilozoficzne w społecznym nauczaniu Jana Pawła II (na przykładzie wybranych encyklik)
}

\section{Wstęp}

Jan Paweł II pozostawił po sobie olbrzymią spuściznę w dziedzinie społecznego nauczania, którego treści do dnia dzisiejszego zachowują swoją aktualność. Warto więc te oryginalne i doniosłe myśli przypominać Czytelnikom. W moim artykule chciałbym skoncentrować się na poglądach Ojca Świętego odnośnie szczegółowych kwestii ochrony ludzkiego życia w płaszczyźnie bioetycznej (etyki medycznej) i ekologicznej (ochrony środowiska społeczno-przyrodniczego). Zadanie to postaram się spełnić nawiązując do wybranych papieskich encyklik, pomijając tutaj inne dokumenty, takie jak: adhortacje, listy czy przemówienia.

Artykuł składa się z dwóch zasadniczych części: w pierwszej przedstawione zostały poglądy bioetyczne Jana Pawła II na podstawie lektury encykliki Evangelium vitae (1995); w drugiej zaś ukazane zostały papieskie refleksje dotyczące ochrony środowiska, jakie odnaleźć można w następujących encyklikach: Redemptor hominis (1979); Sollicitudo rei socialis (1987); Centesimus annus (1991) - oraz ponownie - Evangelium vitae (1995). ${ }^{1}$

\section{Refleksje bioetyczne Jana Pawła II w Evangelium vitae (1995)}

Poglądy bioetyczne Ojca Świętego najpełniej zostały przedstawione w encyklice Evangelium vitae (1995)². Jak samej jej podtytuł: „O wartości i nienaruszalności życia ludzkiego" sugeruje, że katolicka teologia moralna i wsparte na niej nauczanie Kościoła - życie ludzkie uznaje za wartość świętą i nienaruszalną, dlatego też taką koncepcję etyczną można byłoby nazwać „bioetyką świętości życia”.

Cytaty z encyklik przytaczam za: Encykliki Ojca Świętego Jana Pawła II, Wyd. ZNAK, Kraków 2005.

2 JaN PAWE€ II, Encyklika Evangelium vitae: o wartości i nienaruszalności życia ludzkiego, Watykan 1995. 
Wspomniana encyklika w całości poświęcona została ukazaniu niezbywalnej wartości i godności ludzkiego życia w kontekście współczesnych zagrożeń cywilizacyjnych. Papież stwierdza, iż współczesna kultura, którą paradoksalnie nazywa „kulturą śmierci” sankcjonuje przestępstwa przeciwko życiu ludzkiemu, do których zalicza: zabójstwo, ludobójstwo, aborcję, eutanazję, samobójstwo, jak i inne niegodziwe czyny, które naruszają „całość osoby ludzkiej, jak okaleczenia, tortury zadawane ciału i duszy, próby wywierania przymusu psychicznego; wszystko, co ubliża godności ludzkiej, jak nieludzkie warunki życia, arbitralne aresztowania, deportacje, niewolnictwo, prostytucja, handel kobietami i młodzieżą; a także nieludzkie warunki pracy, w których traktuje się pracowników jak zwykłe narzędzia zysku, a nie jak wolne odpowiedzialne osoby (...)”. (EV 3). Papież zauważa, iż w cywilizacji wspartej na „kulturze śmierci” często wiele niegodziwych działań mających na celu przerwanie ludzkiego życia (takich, jak np. aborcja czy eutanazja), zostaje przez dużą część opinii publicznej usprawiedliwiana prawem do wolności wyboru, prowadząc ostatecznie do ich prawnej legalizacji. Jan Paweł II ubolewa również nad tym, że współczesna medycyna, która powinna stać na straży ochrony ludzkiego życia często wykorzystywana jest do zamachów na życie (EV 4).

Papież zauważa, iż oprócz tych powszechnie znanych przestępstw przeciwko życiu człowieka, obecnie mamy do czynienia z nowymi głęboko niemoralnymi praktykami. Zalicza do nich techniki sztucznego zapłodnienia, które prowadzą do dehumanizacji procesu przekazywania życia oraz narażają „nadliczbowe” embriony pozostałe po zapłodnieniu pozaustrojowym na śmierć (EV 14). Za moralnie złe uznaje eksperymenty medyczne na embrionach ludzkich oraz traktowania ich jako rezerwuaru narządów i tkanek do transplantacji (EV 63). Zdecydowany sprzeciw Jana Pawła II wywołują także te odmiany badań prenatalnych, które po wykryciu anomalii we wczesnym rozwoju płodu dają podstawę do usunięcia ciąży. Moralnie godziwe są natomiast takie metody diagnostyczne, które umożliwiają terapię (EV 63).

Sprzeciw moralny wzbudza również polityka antynatalistyczna mająca stanowić remedium na eksplozję demograficzną. \aki sposób uprawiania polityki w istocie może stanowić poważne zagrożenia dla godności i życia człowieka. Polityka, która za pomocą antykoncepcji, sterylizacji i aborcji ma rozwiązać ten problem, jest nie tylko niegodziwa, ale przede wszystkim nieskuteczna, gdyż „Wobec problemu przeludnienia krajów ubogich społeczność międzynarodowa nie podejmuje odpowiednich działań na skalę globalną - poważnej polityki rodzinnej i społecznej oraz programów zmierzających do postępu kulturowego i do sprawiedliwszego podziału dóbr (...)”. (EV 16).

Jan Paweł II apeluje do ludzi dobrej woli, w tym również do osób odpowiedzialnych za kreowanie polityki państwowej, do tego, aby współczesną cywilizację zbudować na takich podstawach kulturowych, które uznają nieporówny- 
walną wartość ludzkiej osoby, a więc na „Ewangelii życia”. Jak zauważa: „Mimo wszelkich trudności i niepewności każdy człowiek szczerze otwarty na prawdę i dobro może dzięki światłu rozumu i pod wpływem tajemniczego działania łaski rozpoznać w prawie naturalnym wypisanym w sercu (por. Rz 2,14-15) świętość ludzkiego życia od poczęcia aż do kresu oraz dojść do przekonania, że każda ludzka istota ma prawo oczekiwać absolutnego poszanowania tego swojego podstawowego dobra. Uznanie tego prawa stanowi fundament współżycia między ludźmi oraz istnienia wspólnoty politycznej". (EV 2).

\section{Ekologia humanistyczna w przesłaniu społecznym Jana Pawła II}

W tej części pracy odniosę się do tych encyklik, wymienionych na wstępie artykułu, w których odnaleźć można obszerne fragmenty poświęcone kwestii ekologicznej.

\subsection{Encyklika Redemptor hominis (1979)}

Dojrzewanie myśli ekologicznej można już dostrzec w pierwszej encyklice Ojca Świętego. ${ }^{3}$ Zwrócił w niej uwagę na pewne kwestie składające się na relacje człowieka do przyrody, na tle innych współczesnych zagrożeń, które dotykają współczesnego człowieka (por. RH 13-17). „Ôw stan zagrożenia człowieka ze strony wytworów samego człowieka ma różne kierunki i różne stopnie nasilenia. Zdaje się, że jesteśmy coraz bardziej świadomi, iż eksploatacja Ziemi, planety, na której żyjemy, domaga się jakiegoś racjonalnego i uczciwego planowania. Równocześnie eksploatacja ta dla celów nie tylko przemysłowych, ale także militarnych, nie kontrolowany wszechstronnym i autentycznie humanistycznym planem rozwój techniki, niesie z sobą często zagrożenie naturalnego środowiska człowieka, alienuje go w stosunku do przyrody, odrywa od niej. Człowiek zdaje się często nie dostrzegać innych znaczeń swego naturalnego środowiska, jak tylko te, które służą celom doraźnego użycia i zużycia. Đymczasem Stwórca chciał, aby człowiek obcował z przyrodą jako jej rozumny i szlachetny «pan» i «stróż», a nie jako bezwzględny «eksploatator»". (RH 15).

Zaakcentowany został tutaj chrześcijański teocentryzm, który ukazuje właściwy stosunek człowieka do przyrody, zaś postęp w obrębie współczesnej cywilizacji technicznej należy „zrównoważyç" proporcjonalnym rozwojem moralności i etyki.

\subsection{Encyklika Sollicitudo rei socialis (1987)}

W tej społecznej encyklice Jan Paweł II uznaje doniosłość wagi ochrony środowiska podkreślając, iż „Wśród pozytywnych znaków obecnych czasów należy

3 Jan PAWE⿺ II, Encyklika Redemptor hominis, Watykan 1979.

4 JAN PAWEe II, Encyklika Sollicitudo rei socialis, Watykan 1987. 
też odnotować rosnącą świadomość ograniczoności dostępnych zasobów, potrzeby poszanowania integralności i rytmów natury oraz uwzględniania ich przy programowaniu rozwoju, nie poświęcając ich na rzecz demagogicznych koncepcji. Chodzi tu o tak zwaną dzisiaj troskę ekologiczną." (SRS 26).

Papież zwraca uwagę na właściwy, prawdziwy rozwój człowieka, który nie może bazować jedynie na zaspokajaniu doczesnych, materialnych pragnień, musi bowiem dotyczyć również jego sfery transcendentnej i być ukierunkowany moralnie. \en „Moralny charakter rozwoju nie może także pomijać milczeniem poszanowania bytów tworzacych widzialną naturę, którą Grecy (...) nazywali «kosmosem»". (SRS 34). W jego skład Jan Paweł II zalicza różnego rodzaju byty przyrodnicze (składniki naturalne, rośliny, zwierzęta), których nie wolno dowolnie i bezkarnie używać dla własnych celów gospodarczych, ponieważ:

1) narusza się w ten sposób ich wewnętrznie uporządkowany system (kosmos);

2) są one nieodnawialne, dlatego należy zachować je dla przyszłych pokoleń;

3) skutki nadmiernie postępującego rozwoju przemysłowego zatruwają środowisko życia człowieka obniżając jego jakość i narażając ludzkość na niepotrzebne choroby.

Ojciec Święty przywołuje w tym kontekście teologiczny argument, że świat (kosmos) został stworzony przez Boga, za który człowiek jest szczególnie odpowiedzialny. Papież zwraca także uwagę, że człowiek jest częścią przyrody podlegając jej prawom, ale także uzależniony jest od praw moralnych, których nie wolno mu naruszać. (SRS 34).

\subsection{Encyklika Centesimus annus (1991)}

W encyklice tej ${ }^{5}$ po raz pierwszy użyto sformułowań: „ekologia ludzka” i „ekologia społeczna”. Papież zwraca uwagę, iż współczesna kultura zdominowana przez konsumizm, prowadzi do wielu wypaczeń, z których wyrasta również kwestia ekologiczna. „Człowiek, opanowany pragnieniem posiadania i używania, bardziej aniżeli bycia i wzrastania, zużywa w nadmiarze i w sposób nieuporządkowany zasoby ziemi, narażając przez to także własne życie. U korzeni bezmyślnego niszczenia środowiska naturalnego tkwi błąd antropologiczny, niestety rozpowszechniony w naszych czasach. (...) Człowiek mniema, że samowolnie może rozporządzać ziemią, podporządkowując ją bezwzględnie własnej woli, tak jakby nie miała ona własnego kształtu i wcześniejszego, wyznaczonego jej przez Boga, przeznaczenia, które człowiek, owszem, może rozwijać lecz któremu nie może się sprzeniewierzać. Zamiast pełnić rolę współpracownika Boga w dziele stworzenia, człowiek zajmuje Jego miejsce i w końcu prowokuje bunt natury, raczej przez niego tyranizowanej niż rządzonej”. (CA 37).

Jan PaWe€ II, Encyklika Centesimus annus, Watykan 1991. 
W dokumencie tym zwrócono także uwagę, iż słuszny postulat ochrony środowiska naturalnego musi zostać uzupełniony o ochronę „środowiska ludzkiego", gdyż współcześnie „zbyt mało wagi przywiązuje się do ochrony warunków moralnych prawdziwej «ekologii ludzkiej»”. (CA 38). „W tym kontekście należy wspomnieć o poważnych problemach współczesnej urbanizacji, konieczności urbanistyki troszczącej się o życie osoby, jak również o należytym zwracaniu uwagi na «społeczną ekologię» pracy". (CA 38).

Podstawą tak rozumianej „ekologii ludzkiej” jest rodzina oparta na ma1żeństwie, stanowiąca "sanktuarium życia”. „Istotnie bowiem jest ona święta: jest miejscem, w którym życie, dar Boga, może w sposób właściwy być przyjęte i chronione przed licznymi atakami, na które jest ono wystawione, może też rozwijać się zgodnie $\mathrm{z}$ wymogami prawdziwego ludzkiego wzrostu. Wbrew tak zwanej kulturze śmierci, rodzina stanowi ośrodek kultury życia”. (CA 39).

Ojciec Święty zwraca także uwagę na obowiązek państwa, gdyż powinno ono zagwarantować zabezpieczenie dóbr społecznych, których nie można traktować w kategoriach towaru podlegającego prawom rynku. Środowisko naturalne i środowisko ludzkie właśnie należą do takich niezbywalnych dóbr (CA 40).

\subsection{Encyklika Evangelium vitae (1995)}

W encyklice tej ${ }^{6}$, która - przypomnę - poświęcona została współczesnym zagrożeniom dla ludzkiego życia jakie niesie „kultura śmierci”, znajdują się również wątki ekologiczne, jakie podnosi w tym kontekście papież. Jak sam stwierdza „Jakże nie wspomnieć tu o przemocy wymierzonej przeciw życiu milionów istot ludzkich, zwłaszcza dzieci, zmuszonych znosić nędzę, niedożywienie i głód z powodu niesprawiedliwego podziału zasobów ziemi między poszczególne narody i klasy społeczne? O przemocy nieodłącznie związanej nie tylko z wojną, ale także z gorszącym handlem bronią, który przyczynia się do zaostrzenia licznych konfliktów zbrojnych nękających świat? O zasiewie śmierci, jaki dokonuje się przez bezmyślne naruszanie równowagi ekologicznej, przez zbrodniczy handel narkotykami i przez propagowanie wzorców zachowań w dziedzinie życia płciowego, które nie tylko są moralnie nie do przyjęcia, ale rodzą także poważne niebezpieczeństwa dla życia?”. (EV 10).

Dlatego „Należy z zadowoleniem powitać także wzrost zainteresowania jakościa życia oraz ekologia, jaki nastąpił zwłaszcza w społeczeństwach o wysokim stopniu rozwoju, w których ludzie dążą już nie tylko do zapewnienia sobie podstawowych środków do życia, ile do globalnego polepszenia warunków życia”. (EV 27).

Rozdział 42. tej encykliki jest kluczowy dla podjętych w niej zagadnień ekologicznych. Zostały one ukazane w kontekście umacniania i obrony życia - zada-

6 Jan PaWEe II, Encyklika Evangelium vitae: o wartości i nienaruszalności życia ludzkiego, Watykan 1995. 
nia, które „Bóg powierza każdemu człowiekowi, powołując go - jako swój żywy obraz - do udziału w Jego panowaniu nad światem (...)" (EV 42) - które zostało wyartykułowane w stynnym fragmencie z Księgi Rodzaju (Rdz 1, 28). Nie oznacza jednak ono - jak niesłusznie powszechnie się sądzi - zgodę na nieumiarkowaną eksploatację przyrody, ponieważ człowiek „został powołany, aby uprawiać ogród ziemi i strzec go (por. Rdz 2,15), jest zatem w szczególny sposób odpowiedzialny za środowisko życia, to znaczy za rzeczywistość stworzoną, która z woli Boga ma służyć jego osobowej godności i jego życiu: odpowiedzialny nie tylko wobec obecnej epoki, ale i przysztych pokoleń". (EV 42).

Panowanie człowieka nie jest więc absolutne, trudno więc oskarżać chrześcijaństwo o skrajnie posunięty antropocentryzm, gdyż mamy tu w istocie do czynienia z teocentryczną wizją ochrony środowiska. „Ograniczenie nałożone od początku na człowieka przez samego Stwórcę i wyrażone w sposób symboliczny w zakazie «spożywania owocu drzewa» (por. Rdz 2, 16-17) jasno ukazuje, że w odniesieniu do widzialnej natury jesteśmy poddani prawom nie tylko biologicznym, ale także moralnym, których nie można bezkarnie przekraczać". (EV 42).

$\mathrm{Na}$ marginesie chciałbym zwrócić uwagę na jeszcze dwa fragmenty encykliki, które również można byłoby wpisać w kontekst ekologiczny. Dotyczą one wyjątkowości człowieka w świecie przyrody. Mogłyby one stanowić argument natury teologicznej przeciwko naturalistycznej wizji człowieka, do której nawiązują często biocentryczne ideologie na gruncie ekoetyki. Papież zmartwiony jest faktem, że „Człowiek nie potrafi już postrzegać samego siebie jako kogoś «przedziwnie odmiennego» od innych ziemskich stworzeń; uznaje, że jest tylko jedną z wielu istot żyjących, organizmem, który - w najlepszym razie - osiągnął wysoki stopień rozwoju. Zamknięty w ciasnym kręgu swojej natury, staje się w pewien sposób «rzeczą) i przestaje rozumieć «transcendentny» charakter tego, że «istnieje jako człowiek»". (EV 22). W myśl katolickiej teologii to człowiek - a nie inne byty ożywione świata przyrody - jest koroną stworzenia. Jak ukazuje Biblia został on stworzony w szóstym dniu, jako zwieńczenie wszechświata (EV 35). Naturalnie jego władza nad światem przyrody ma charakter opiekuńczy, a nie eksploatorski.

\section{Zakończenie}

Zamiast tradycyjnego zakończenia, chciałbym powyższe uwagi poświęcone bioetyce i ekofilozofii podsumować nawiązując do jeszcze jednej papieskiej encykliki Fides et ratio $(1998)^{7}$, w której Ojciec Święty zwraca uwagę na „niebezpieczeństwo, że niektórzy ludzie nauki, rezygnując z jakichkolwiek odniesień etycznych, nie stawiają już w centrum swej uwagi osoby ludzkiej i całości jej życia.

Jan PAWEe II, Encyklika Fides et ratio, Watykan 1998. 
Co więcej, część z nich, świadoma możliwości otwartych przez rozwój techniki, wydaje się ulegać nie tylko logice rynku, ale także pokusie zdobycia demiurgicznej władzy nad przyrodą, a nawet nad samym bytem ludzkim". (FR 46).

Reasumując Papież zdecydowanie podkreśla, iż rozwój naukowo-techniczny oraz ustrój demokratyczny, który nie bazuje na wartościach moralnych oraz metafizyce uznającej transcendentny wymiar rzeczywistości, może doprowadzić do wielu zagrożeń dla środowiska życia człowieka, zarówno w bioetycznym, społecznym, jak i ekologicznym wymiarze.

\section{Ethical and bioethical stances of John Paul II}

\section{SUMMARY}

John Paul II has left behind a huge legacy of social teaching which retain its value till the present days therefore it is worth to remind the readers his significant ideas. In my article I familiarized readers with stances of John Paul II related to specific issues on medical ethicists and ecological aspects of human life protection based upon papal encyclicals. The article consists of two main parts: first refers to pope's bioethical stances existed in encyclical Evangelium vitae (1995); the second one presented pope's thoughts on environmental protection which could be find in the following encyclicals: Redemptor hominis (1979); Sollicitudo rei socialis (1987); Centesimus annus (1991) - and again in - Evangelium vitae (1995). 